\title{
9: 35070013-35063835
}

National Cancer Institute

\section{Source}

National Cancer Institute. 9: 35070013-35063835. NCI Thesaurus. Code C42245.

Physical location of FANCG_Gene 